Floresta e Ambiente 2020; 27(1): e20170979

https://doi.org/10.1590/2179-8087.097917

ISSN 2179-8087 (online)

ORIGINAL ARTICLE - Silviculture

Floresta e Ambiente

\title{
Phenology of Copernicia alba in Flooded and Not Flooded Environments
}

\author{
Maicon Marinho Vieira Araujo ${ }^{1}$ (1) 0000-0002-7200-4751 \\ Francisco de Almeida Lobo ${ }^{2}$ (1) 0000-0002-5670-0351
}

\begin{abstract}
The objective of this study is to describe the reproductive and vegetative phenological patterns of individuals of Copernicia alba, popularly known as "carandá," in two areas of the Pantanal of Mato Grosso and to test the relations between their phenophases and climatic seasonality. We obtained the phenological aspects of the carandá through a biweekly observation of 22 individuals from two areas of the Pantanal of Mato Grosso between August 2015 and August 2017. The carandá population presented a perennial behavior, flowering during the dry season and greater leaf intensity in the transition period to the rainy season. Budding, although continuous, was intense in the rainy season, and the leaf deciduous pattern had a direct interference from the absence of rainfalls in the dry period. The incidence of floral buds occurred in the dry period, and the flowering occurred between the dry and rainy periods. The fruiting period occurred in the rainy season, indicating a high synchronism of phenophases.
\end{abstract}

Keywords: carandá, flowering, fructification, phenophases.

\section{INTRODUCTION AND OBJECTIVES}

The Pantanal is composed by the intersection of four major phytoecological regions, which are regionally known as Deciduous Forest, Semi-deciduous Forest, Cerrado and Chaco. In addition to these four regions, in several portions of the Pantanal there are floristic contacts among the Phytoecological Regions (Abdon et al., 2007). Although this biome excels in the world conservation scenario because of its high species richness and high rate of endemism, the Pantanal can be considered a biome threatened by the intense and progressive de-characterization caused by anthropic actions (Belo et al., 2013).

An important endemic species in this biome is the Copernicia alba (Morong ex Morong \& Britton), popularly known as "carandá," which belongs to the family Arecaceae (Pott \& Pott, 1994). The estimated carandá area in the Pantanal vegetation is $2.3 \%$, the second most representative monotypic formation. The carandá is also found in phytophysiognomies known as mixed forests, where semi-deciduous forest species are found associated with balloon vine (Tabebuia aurea (Manso) B. and H.) (Fava \& Albuquerque, 2011).

Due to its representativeness, studies aiming to understand and produce knowledge on the behavior of this species can be a basis for strategies of conservation and restoration of this biome. In this case, the study of phenology represents a good tool for understanding the factors that influence the reproduction and survival of plant species, contributing to the understanding of the dynamics and structuring of plant communities (Morellato et al., 1992).

This is because plants present phenological strategies related to the environmental characteristics of their habitats, their habits, reproductive biology and modes of dispersion (Conceição et al., 2007). The interaction between the phenology of a particular plant species and the seasonal variation in climate is one of the most important determinants of its distribution (Chuine \& Beaubien, 2001). Thus, it is expected that endemic species present phenological responses adapted to the peculiarities of the habitat in which they occur.

In addition, understanding the reproductive cycles of plants is of fundamental importance for the conservation and management of native and endangered species. However, phenological studies on plants of the Pantanal biome are scarce, especially in endemic species, such as the carandá (Coelho \& Machado, 2009; Conceição et al., 2007; Dutra et al., 2009; Miola et al., 2011).

The objective of this work is to describe the reproductive and vegetative phenological patterns of individuals of Copernicia alba occurring in flooded and not flooded environments of the

\footnotetext{
${ }^{1}$ Universidade de Cuiabá (UNIC), Cuiabá, MT, Brasil

${ }^{2}$ Universidade Federal de Mato Grosso (UFMT), Cuiabá, MT, Brasil
} 
Pantanal of Mato Grosso, and to test the relationship between their phenophases and climatic seasonality.

\section{MATERIALS AND METHODS}

\subsection{Study areas}

This study was carried out in two municipalities of the state of Mato Grosso using 12 individuals located in the urban region of Cuiabá at the coordinates $15^{\circ} 36^{\prime} 29^{\prime \prime} \mathrm{S}$ and $56^{\circ} 45^{\prime} 16^{\prime \prime} \mathrm{W}$, and 10 individuals located in the Jubran Private Reservation of Natural Heritage in Cáceres at the coordinates $16^{\circ} 53^{\prime} 23.3^{\prime \prime}$ S and 57 $24^{\prime} 22.2^{\prime \prime} \mathrm{W}$, from August 2015 to August 2017.

The climate of the regions is Aw, according to the Köppen classification, that is, semi-humid tropical, with average temperatures of $24-26^{\circ} \mathrm{C}$, four to five dry months and two well defined seasons: a dry (autumn-winter) and a rainy (spring-summer) season, with an annual rainfall index of $1,250-1,500 \mathrm{~mm}$.

The soils of these sites are typical Dystrophic Petric Plinthosol (Valentini et al., 2013). We collected samples of the soils from Cuiabá and Cáceres at a depth of $0-15 \mathrm{~cm}$, presenting, respectively, the following characteristics: $\mathrm{pH}: 5.3$ and 5.5; organic matter: $19 \%$ and $33 \%$; sand: $60 \%$ and $68 \%$; silt: $22 \%$ and $16 \%$; and clay: $18 \%$ and $16 \%$.

\subsection{Phenological data}

For the phenological monitoring of Copernicia alba, the selected individuals were marked and georeferenced. From September 2015 to June 2017, we conducted biweekly evaluations at the study site to monitor vegetative phenophases. In some cases, the sacking deposited under the projection of the canopy where we observed floral buds, new aborted fruits, green fruits, and ripe fruits were only examined for conformation of the current phenophases.

We recorded the percentage of occurrence of the following phenophases (Koptur et al., 1988): (i) budding: period of the occurrence of leaf buds up to the expansion of new leaves; (ii) leaf fall; (iii) flowering: divided into periods with buds and open flowers; and (iv) fruiting, divided in periods with unripe fruits and ripe fruits. We performed observations of the phenophases in the dry and rainy periods. In all data collections, we observed the reproductive and vegetative aspects of each species, noting all the data and obtaining the photographic records for possible comparisons of each phenophase.

\subsection{Data analysis}

We analyzed the data from both places separately and comparatively, according to the following indexes:
(1) Activity index is the percentage of individuals in a given phenophase. For a given moment, the presence (1) or absence (0) of individuals in a phenophase is quantified in relation to the total number $(\mathrm{N})$ of individuals sampled. This index, therefore, allows to evaluate the synchrony of the individuals of a population. The greater the percentage of individuals in the phenophase, the more synchronized they are (Bencke \& Morellato, 2002; Fournier, 1974; Souza et al., 2014).

(2) Fournier Intensity or Fournier Index (Fournier, 1974) provides the abundance data of the phenophase at an evaluated moment. This index is determined by individual evaluations in the sample, assigning a score (E) to each individual according to the following categorization: 0 - no phenomena observed; 1 - presence of the phenomenon observed with a magnitude from 1 to $25 \% ; 2$ - presence of the phenomenon observed with a magnitude from 26 to $50 \% ; 3$ - presence of the phenomenon observed with a magnitude from 51 to $75 \%$; and 4 - presence of the phenomenon observed with a magnitude from 76 to $100 \%$ (Bencke \& Morellato, 2002). The calculation was performed by Equation 1 (Marchioretto et al., 2007):

$$
[\% \text { Fournier }=(\Sigma \text { Fournier } / 4 \mathrm{~N}) \times 100](1)
$$

Where $\Sigma$ Fournier: sum of Fournier categories for each individual; N: number of sample individuals.

In order to analyze how much each phenophase was expressed in a period, that is to say, the amplitude of time in months of each vegetative or reproductive event, we used the methodology proposed by Newstrom et al. (1994). It recognizes three different classes: a short one, in which the event lasts up to one month; an intermediate one, in which the phenophase extends from two to five months; and a long one, in which the phenophase extends for six months or more.

We tested the relations between the occurrence of each phenophase and the climatic variables (air temperature, rainfall, relative humidity, wind speed and radiation) using Spearman correlation and the climatic data of the four fortnights prior to the phenological event (Rocha et al., 2015). Deviations from the normality of phenological data were confirmed by the Kolmogorov-Smirnov test for use of Spearman non-parametric correlation.

\subsection{Weather data}

We obtained climatic data of rainfall $(\mathrm{mm})$ and average temperature $\left({ }^{\circ} \mathrm{C}\right)$, provided by the Instituto Nacional de Meteorologia (INMET), from conventional stations located in the municipalities of Cuiabá and Cáceres (Figures 1 and 2). 


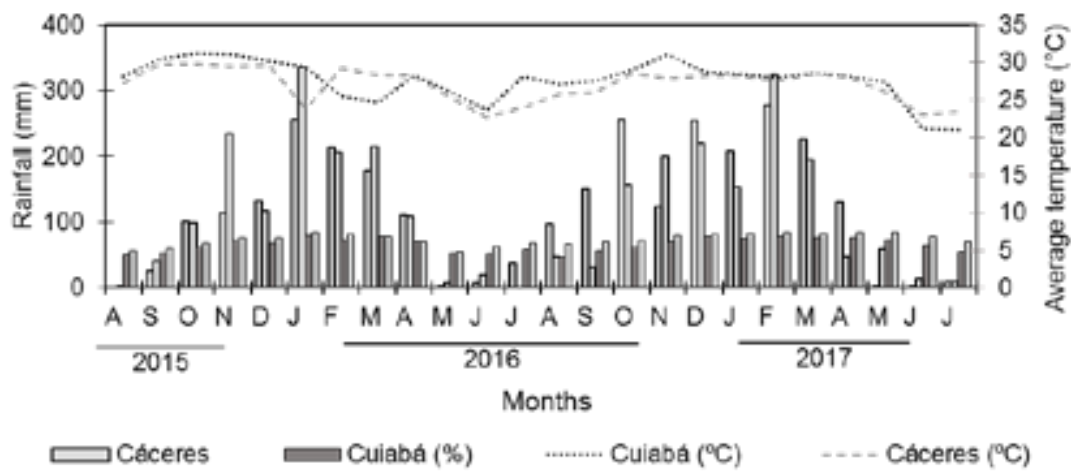

Figure 1. Meteorological data of rainfall $(\mathrm{mm})$ and average temperature $\left({ }^{\circ} \mathrm{C}\right)$ over the evaluation months for the cities of Cuiabá, MT, and Cáceres, MT.Source: INMET (2017)

\section{RESULTS AND DISCUSSION}

The rainfall distribution presented two distinct periods for the regions under study. A rainy period extended from October to April, concentrating the highest rainfall rates, which on average equals to $91 \%$ of the rains, followed by a period of drought from May to September, whose precipitation corresponds to only $9 \%$, characterizing the dry period (Martins et al., 2011).

Leaf fall remained low throughout the observed period. In August and September of 2015 and 2016, there was a markedly vegetative growth of the species for both sites, and the lowest leaf fall percentage. This characterizes the vegetative development of the plant, and it can therefore be classified as perennial (Negrelle \& Degen-Naumannn, 2012).

Other species that also have a perennial leaf behavior were the "cagaiteira" (Eugenia dysenterica Mart.), according to a study by Sano et al. (1995) in the Cerrado region of Planaltina, DF.

The dry period presented the greatest loss of leaves by the species studied, mainly in June and peaking in September. The events of senescence and leaf fall are probably related to the beginning of the dry season, when evapotranspiration increases. Thus, leaf loss in the dry season is a water saving factor for plants, and low moisture indexes stimulate leaf abscission (Vilela et al., 2008).

The proportion of individuals at the budding phenophase was high in the rainy season, between December and January, although it was significant in the other periods. This shows that the species under study maintained the growth and production of new leaves or shoots throughout the period (Figure 2).

The highest Fournier intensity indexes occurred during the period when activity indexes were higher, that is, when all the individuals of the population presented a determined phenophase with the greatest intensity. In this study, the maximum intensity reached by each individual of the population was $27 \%$ of the canopy at the phenophase.
During the rainy season, between December and March, only $5 \%$ of the individuals presented leaf loss, while $40 \%$ of the individuals presented leaf fall during the dry season, between April and August. That is, there was a considerable variation in the number of individuals at this phenophase as they occur mainly due to the availability of water during the observed periods.

The emission flux of new leaves occurred moderately throughout the year, with a higher intensity in October (Figure $2 \mathrm{c}$ and $\mathrm{d}$ ), indicating that the individuals are synchronous with this phenophase and suggesting that the budding occurs at the beginning of the year.

By comparing both indexes, the peaks of activity and intensity of Fournier coincided for the population of C. alba, indicating growth of new buds and leaves throughout the whole period. The Fournier intensity index revealed a continuous pattern of intensity for the leaf fall phenophase, indicating loss of leaves during the observed period. However, it showed a high intensity in the dry period. The coincidence between activity peaks and intensity tends to be more evident in vegetative phenophases, because the cumulative increase in the magnitude of these phenophases is slower and more gradual than in the reproductive phenophase (Bencke \& Morellato, 2002).

The results obtained in this study corroborate those obtained by Coelho \& Machado (2009), who studied the phenology of Heteropterys aphrodisiaca in different regions of Mato Grosso, and observed that the leaf deciduousity appears to suffer a direct interference from the absence of rains during the dry season (between April and August). Fournier activity and intensity indexes were corresponding and proportional, indicating a high synchronization of phenophases.

During the period between July and August, when individuals presented $100 \%$ of flowers with fruits, the peak of intensity for the reproductive phase reached the highest value. At the flowering phenophase (Figure 3a) and at the fruiting phenophase (Figure 3b), the activity and intensity indexes were corresponding and proportional, indicating a high intraspecific synchronicity. 
The flowering of C. alba began in March with about 15\% of individuals with flowers and reached the maximum flowering in September, with $90 \%$ of individuals with flowers. On the other hand, the fruiting phenophase began at the peak of the flowering (September), extending until June, presenting an intense fruit production in February and an asynchronous behavior in the flowering period. Salgado (2006) associated flowering in the dry season with conditions conducing to the dispersion of pollen in anemophilous species.
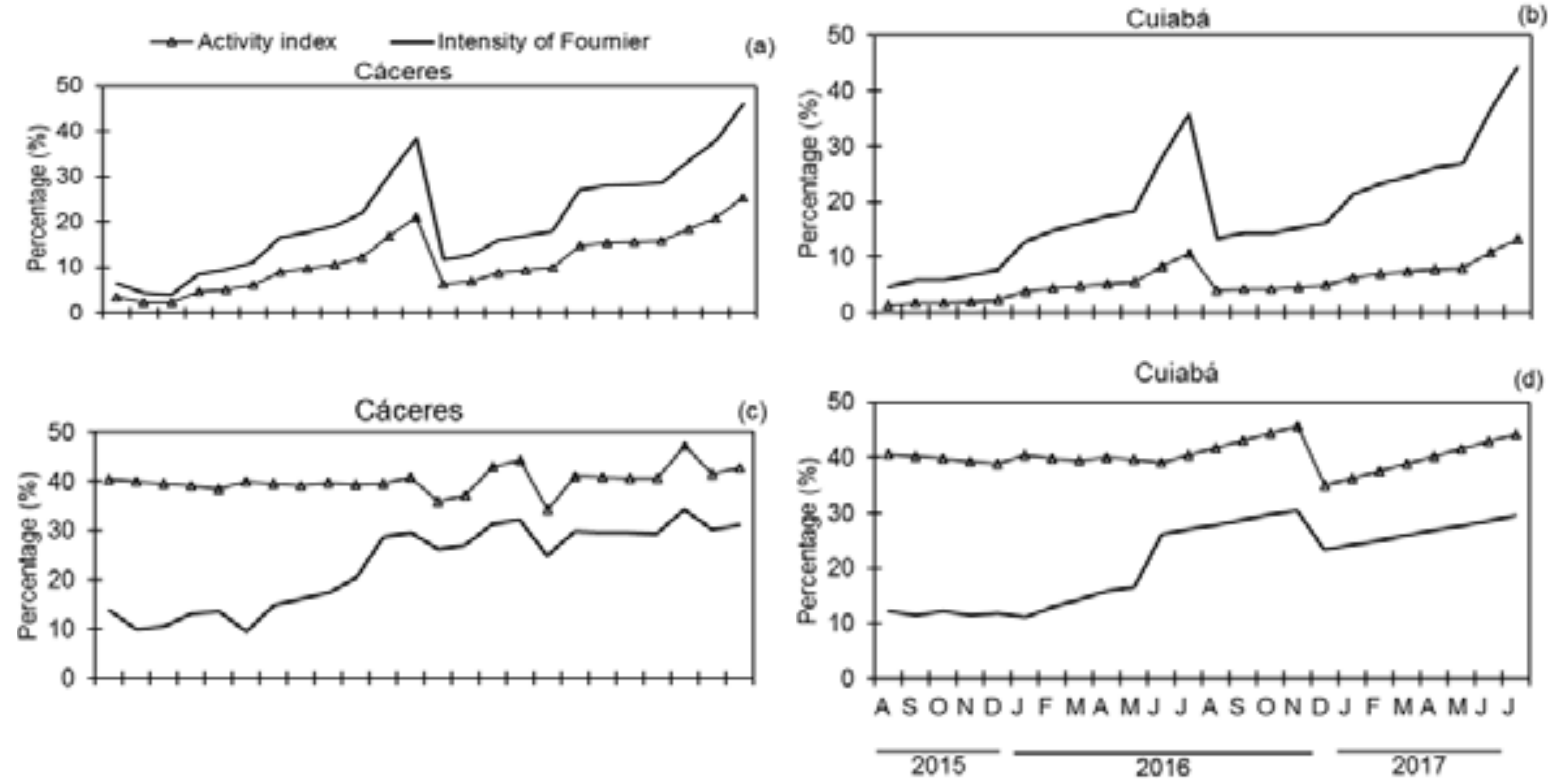

Figure 2. Activity index and intensity of Fournier for vegetative phenology of individuals of Copernicia alba in the municipalities of Cáceres and Cuiabá, MT.

(a) and (b) leaf fall; (c) and (d) budding.'
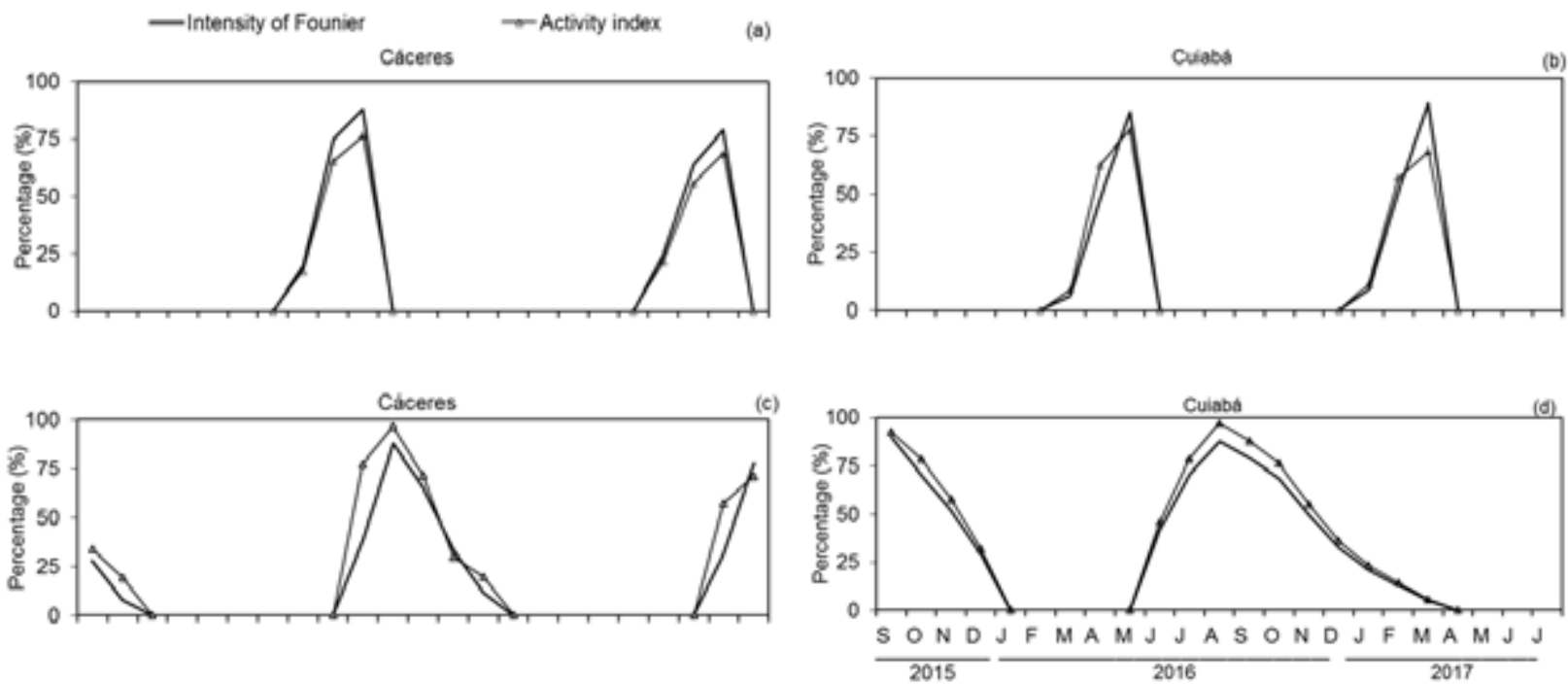

Figure 3. Reproductive phenology of individuals of Copernicia alba in the municipalities of Cáceres and Cuiabá, MT.

(a) and (b) flower buds; (c) and (d) open flowers. 

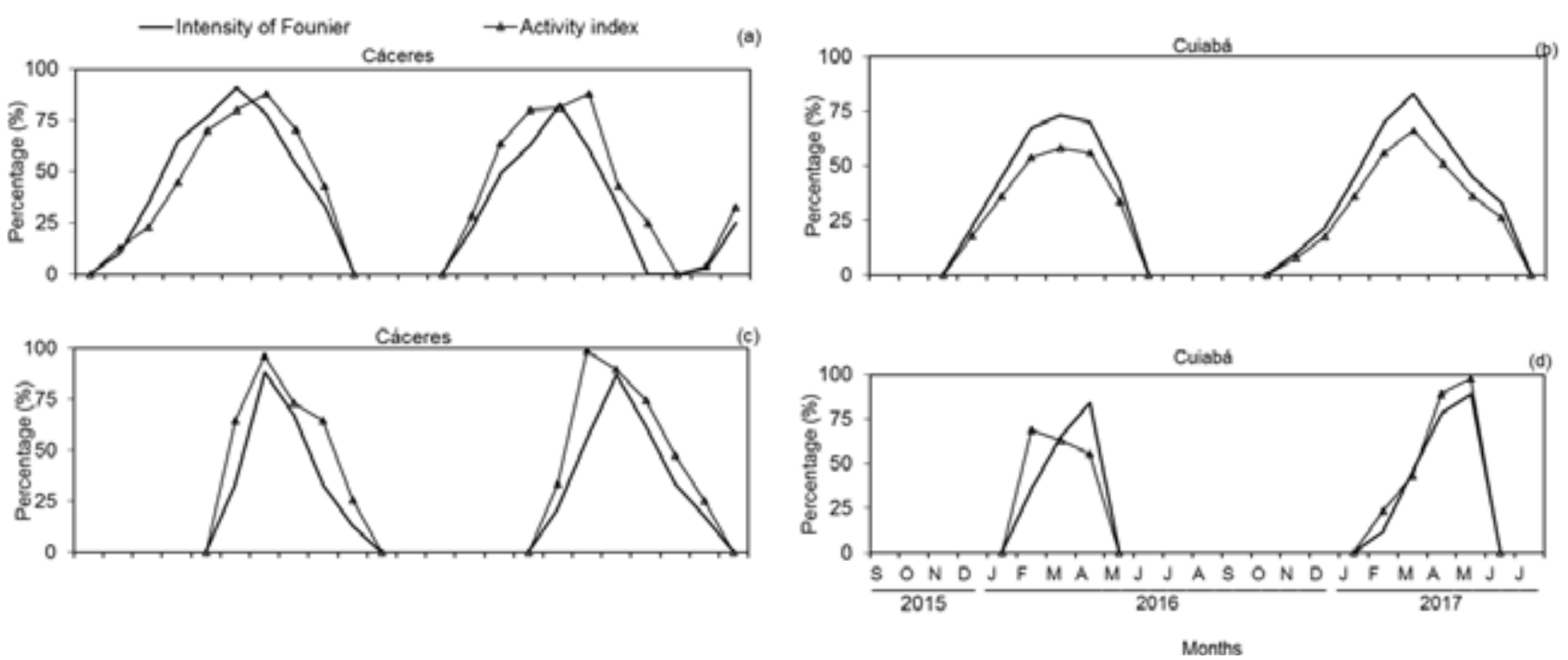

Figure 4. Reproductive phenology of individuals of Copernicia alba in the municipalities of Cuiabá and Cáceres, MT.

(a) and (b) unripe fruits; (c) and (d) ripe fruits.

According to the pattern described by Piña-Rodrigues \& Aguiar (1993) in anemocorous species, fruit production and ripening occur in shorter periods (two to three months). In addition, fruit and seed production is abundant, usually concentrated in a particular time of the year, and fruit ripening is fast, with little variation within the same individual. The ripening, dispersal and ripening times of fruits and seeds may occur during the dry season for some species such as Tabebuia avellanedae, Schizolobium parahyba, Copernicia cerifera, Cedrela fissilis, Cordia trichotoma, among others.

Leaf loss correlated significantly with climatic variables, with the exception of wind speed, and Fournier intensity index during the four fortnights prior to the occurrence of the phenological event (Table 1).

Table 1. Spearman correlations (rS) between biweekly averages of climatic variables and vegetative phenological events of Copernicia alba.

\begin{tabular}{|c|c|c|c|c|c|}
\hline \multirow{2}{*}{ Climate variables } & \multirow{2}{*}{ Fortnight } & \multicolumn{2}{|c|}{ Leaf loss } & \multicolumn{2}{|c|}{ Budding } \\
\hline & & Activity & Fournier & Activity & Fournier \\
\hline \multirow{4}{*}{$\mathrm{T}^{\circ} \mathrm{C}$} & $1^{\circ}$ & ns & 0.664 & ns & Ns \\
\hline & $2^{\circ}$ & ns & 0.648 & ns & Ns \\
\hline & $3^{\circ}$ & ns & 0.599 & ns & -0.256 \\
\hline & $4^{\circ}$ & ns & 0.545 & ns & -0.283 \\
\hline \multirow{4}{*}{ Rainfall } & $1^{\circ}$ & ns & -0.404 & ns & Ns \\
\hline & $2^{\circ}$ & ns & -0.435 & ns & Ns \\
\hline & $3^{\circ}$ & ns & -0.361 & ns & Ns \\
\hline & $4^{\circ}$ & ns & -0.400 & ns & Ns \\
\hline \multirow{4}{*}{ RH\% } & $1^{\circ}$ & ns & -0.260 & ns & Ns \\
\hline & $2^{\circ}$ & ns & -0.288 & ns & Ns \\
\hline & $3^{\circ}$ & $\mathrm{ns}$ & -0.325 & $\mathrm{~ns}$ & Ns \\
\hline & $4^{\circ}$ & ns & ns & ns & Ns \\
\hline \multirow{4}{*}{ Wind speed } & $1^{\circ}$ & ns & ns & ns & Ns \\
\hline & $2^{\circ}$ & ns & ns & ns & Ns \\
\hline & $3^{\circ}$ & ns & ns & ns & Ns \\
\hline & $4^{\circ}$ & ns & ns & ns & Ns \\
\hline \multirow{4}{*}{ Radiation } & $1^{\circ}$ & ns & 0.498 & ns & Ns \\
\hline & $2^{\circ}$ & ns & 0.574 & ns & Ns \\
\hline & $3^{\circ}$ & ns & 0.597 & ns & Ns \\
\hline & $4^{\circ}$ & ns & 0.540 & ns & Ns \\
\hline
\end{tabular}

ns: not significant correlation $(\alpha=0.05)$; ${ }^{\circ} \mathrm{C}$ : average temperature; RH\%: relative humidity. 
Plants may present a delayed phenological response to a given environmental stimulus (Marques et al., 2004; Rocha et al., 2015). Thus, leaf fall may be related to climatic factors before the events, that is, an increase in temperature and radiation and a decrease in rainfall and relative humidity may have determined the loss of leaves.

In a study of the phenology of Copernicia prunifera in a Caatinga area of Rio Grande do Norte, Rocha et al. (2015) showed a positive correlation between the leaf fall phenophase and climatic variables. The authors attributed to the water stress, imposed to the population of plants analyzed, a determining factor to leaf abscission. The decrease in the volume of water in the most superficial layers of the soil at the beginning of the dry season has been associated with leaf fall (Rebelatto et al., 2013). Thus, the decrease in water potential may have induced leaf fall in carandá.

The emergence of flower buds showed a significant correlation with all climatic variables analyzed. Thus, the increase in temperature, rainfall and relative air humidity results in a greater emission of flower buds. On the other hand, the increase in wind speed and radiation results in a lower emission of buds (Table 2).

Flower opening showed a positive correlation with average temperature in the last three fortnights that preceded the event and with the rainfall in the last fortnight evaluated.
The last two fortnights showed a significant negative correlation with global radiation. Therefore, flower opening may be associated with later climatic conditions, indicating a high influence of temperature increase and rainfall and the decrease in global radiation in the third and/or fourth fortnight before this event.

Fruiting presented a low correlation with climatic variables. The relation between unripe fruits and the period of higher temperature in the fourth week preceding the event is indicated by the positive correlation (Table 2). The decrease in wind speed in the second and third weeks prior to fruiting significantly influences the production of unripe fruits.

Rocha et al. (2015) found that fruiting in C. prunifera is related to rainfall and that the influence of climate is complex, since each climatic variable seems to have a different weight in the phenology of the species. In fact, the occurrence and intensity of a particular phenophase are usually associated with one or several abiotic factors acting together, such as temperature, rainfall, moisture and nutrient availability, and biotic factors, such as pollinators, dispersants, seed predators and herbivores (Nazareno \& Reis, 2012; Vilela et al., 2008). Therefore, for the evaluation of the interference of biotic and abiotic factors with phenological patterns, it is necessary to carry out a long-term phenological monitoring for several reproductive cycles.

Table 2. Spearman correlations (rS) between biweekly averages of climatic variables and reproductive phenological events of Copernicia alba.

\begin{tabular}{|c|c|c|c|c|c|c|c|c|c|}
\hline \multirow{2}{*}{$\begin{array}{c}\text { Climate } \\
\text { variables }\end{array}$} & \multirow{2}{*}{ Fortnight } & \multicolumn{2}{|c|}{ Floral Buttons } & \multicolumn{2}{|c|}{ Open flowers } & \multicolumn{2}{|c|}{ Unripe fruits } & \multicolumn{2}{|c|}{ Ripe fruits } \\
\hline & & Activ. & Fournier & Activ. & Fournier & Activ. & Fournier & Activ. & Fournier \\
\hline \multirow{4}{*}{$\mathrm{T}^{\circ} \mathrm{C}$} & $1^{\circ}$ & 0.144 & 0.160 & ns & ns & ns & ns & ns & 0.611 \\
\hline & $2^{\circ}$ & 0.156 & 0.172 & 0.444 & 0.468 & ns & ns & ns & 0.601 \\
\hline & $3^{\circ}$ & 0.207 & 0.223 & 0.436 & 0.46 & ns & ns & ns & 0.566 \\
\hline & $4^{\circ}$ & 0.256 & 0.272 & 0.488 & 0.512 & 0.388 & 0.499 & ns & 0.567 \\
\hline \multirow{4}{*}{ Rainfall } & $1^{\circ}$ & 0.488 & 0.504 & ns & ns & ns & ns & ns & ns \\
\hline & $2^{\circ}$ & 0.482 & 0.498 & ns & 0.278 & ns & ns & ns & ns \\
\hline & $3^{\circ}$ & 0.488 & 0.504 & ns & ns & ns & ns & ns & ns \\
\hline & $4^{\circ}$ & 0.501 & 0.517 & 0.187 & ns & ns & ns & ns & 0.198 \\
\hline \multirow{4}{*}{ RH\% } & $1^{\circ}$ & 0.417 & 0.433 & ns & ns & ns & ns & ns & 0.398 \\
\hline & $2^{\circ}$ & 0.499 & 0.515 & ns & $\mathrm{ns}$ & ns & ns & ns & 0.301 \\
\hline & $3^{\circ}$ & ns & ns & ns & ns & ns & ns & ns & ns \\
\hline & $4^{\circ}$ & ns & ns & ns & ns & ns & ns & ns & ns \\
\hline \multirow{4}{*}{ Wind speed } & $1^{\circ}$ & -0.209 & -0.309 & ns & ns & ns & ns & ns & ns \\
\hline & $2^{\circ}$ & -0.251 & -0.351 & ns & ns & ns & 0.201 & ns & ns \\
\hline & $3^{\circ}$ & ns & ns & ns & ns & 0.477 & 0.469 & ns & ns \\
\hline & $4^{\circ}$ & ns & ns & ns & ns & ns & ns & ns & ns \\
\hline \multirow{4}{*}{ Radiation } & $1^{\circ}$ & -0.502 & -0.414 & ns & ns & ns & ns & ns & ns \\
\hline & $2^{\circ}$ & -0.477 & -0.389 & ns & ns & ns & ns & ns & ns \\
\hline & $3^{\circ}$ & ns & ns & -0.333 & -0.354 & ns & ns & ns & ns \\
\hline & $4^{\circ}$ & ns & ns & -0.387 & -0.837 & ns & ns & ns & ns \\
\hline
\end{tabular}

Activ.: intensity of activity; ns: not significant correlation $(\alpha=0.05)$; ${ }^{\circ} \mathrm{C}$ : average temperature; $\mathrm{RH} \%$ : relative humidity. 


\section{CONCLUSIONS}

The carandá (Copernicia alba) is a perennial species with a great loss of leaves in the dry period, and a greater leaf intensity in the transition period between the rainy season and the dry season.

We observed sprouting throughout the year. However, peaks of activity and intensity of Copernicia alba, for both sites, also occurred at the end of the rainy season.

The incidence of floral buds occurred in the dry period and an intense flowering in the transition between the dry and rainy periods. The fruiting period occurred only in the rainy season.

Fournier activity and intensity indexes were corresponding and proportional, indicating a high intraspecific synchronization of phenophases.

\section{ACKNOWLEDGEMENTS}

Coordenação de Aperfeiçoamento de Pessoal de Nível Superior (Capes).

\section{SUBMISSION STATUS}

Received: 30 Sept. 2017

Accepted: 8 Aug. 2018

Associate editor: João Vicente de Figueiredo Latorraca (D) 0000-0002-5969-5199

\section{CORRESPONDENCE TO}

\section{Maicon Marinho Vieira Araujo}

Universidade de Cuiabá (UNIC), Av. Manoel José de Arruda, 3.100, CEP 78065-900, Cuiabá, MT, Brasil

e-mail: maiconmarinho@outlook.com

\section{FINANCIAL SUPPORT}

Coordenação de Aperfeiçoamento de Pessoal de Nível Superior (Capes).

\section{REFERENCES}

Abdon MM, Silva JSV, Souza ÍM, Romon VT, Rampazzo J, Ferrari DL. Desmatamento no bioma pantanal até o ano 2002: relações com a fitofisionomia e limites municipais. Revista Brasileira de Cartografia 2007; 59(1): 17-24.

Belo RM, Negreiros D, Fernandes GW, Silveira FAO, Ranieri BD, Morellato PC. Fenologia reprodutiva e vegetativa de arbustos endêmicos de campo rupestre na Serra do Cipó, Sudeste do Brasil. Rodriguésia 2013; 64(4): 817-828. 10.1590/S2175-78602013000400011

Bencke CSC, Morellato LPC. Comparação de dois métodos de avaliação da fenologia de plantas, sua interpretação e representação. Revista Brasileira de Botânica 2002; 25(3): 269-275. 10.1590/S0100-84042002000300003

Chuine I, Beaubien EG. Phenology is a major determinant of tree species range. Ecology Letters 2001; 4(5): 500-510. 10.1046/j.14610248.2001.00261.x

Coelho AG, Machado CG. Fenologia reprodutiva de Prepusa montana Mart. (Gentianaceae) em uma área de campo rupestre da Chapada Diamantina, BA, Brasil. Revista Brasileira de Botânica 2009; 32(2): 405-410. 10.1590/S0100-84042009000200018

Conceição AA, Funch LS, Pirani JR. Reproductive phenology, pollination and seed dispersal syndromes on sandstone outcrop vegetation in the "Chapada Diamantina", northeastern Brazil: population and community analyses. Revista Brasileira de Botânica 2007; 30(3): 475-485. 10.1590/S0100-84042007000300012

Dutra VF, Vieira MF, Garcia FCP, Lima HC. Fenologia reprodutiva, síndromes de polinização e dispersão em espécies de Leguminosae dos campos rupestres do Parque Estadual do Itacolomi, Minas Gerais, Brasil. Rodriguésia 2009; 60(2): 371-387. 10.1590/2175-7860200960210

Fava CLF, Albuquerque MCF. Emergência de plântulas de Copernicia alba (Morong ex Morong e Britton) em função da escarificação mecânica e imersão de sementes em água corrente. Revista Brasileira de Horticultura Ornamental 2011; 17(2): 127-132. 10.14295/rbho.v17i2.708

Fournier LA. Un método cuantitativo para la medición de características fenológicas en árboles. Turrialba 1974; 24: 422-423.

Instituto Nacional de Meteorologia do Brasil - INMET. Normais climatológicas (2015/2017). Brasília, DF, 2017.

Koptur S, Haber WA, Frankie GW, Baker HG. Phenological studies of shrub and treelet species in tropical cloud forests of Costa Rica. Journal of Tropical Ecology 1988; 4(4): 323-346. 10.1017/S0266467400002984

Marchioretto MS, Mauhs J, Budke JC. Fenologia de espécies arbóreas zoocóricas em uma floresta psamófila no sul do Brasil. Acta Botanica Brasilica 2007; 21(1): 193-201. 10.1590/S0102-33062007000100018

Marques MCM, Roper JJ, Salvalaggio APB. Phenological patterns among plant life-forms in a subtropical forest in Southern Brazil. Plant Ecology 2004; 173(2):203-213. 10.1023/B:VEGE.0000029325.85031.90

Martins JA, Dallacort R, Inoue MH, Galvanin EAS, Magnani EBZ, Oliveira KC. Caracterização do regime pluviométrico no arco das nascentes do rio Paraguai. Revista Brasileira de Meteorologia 2011; 26(4): 639-647. 10.1590/S0102-77862011000400013

Miola DTB, Freitas CR, Barbosa M, Fernandes GW. Modeling the spatial distribution of the endemic and threatened palm shrub Syagrus glaucescens (Arecaceae). Neotropical Biology and Conservation 2011; 6(2): 78-84. 10.4013/nbc.2011.62.02

Morellato LPC, Leitão Filho HF. Padrões de frutificação e dispersão na Serra do Japi. In: Morellato LPC, editor. História natural da Serra do Japi: ecologia e preservação de uma área florestal no Sudeste do Brasil. Campinas: Editora Unicamp; 1992. p. 112-141.

Nazareno AG, Reis MS. Linking phenology to mating system: exploring the reproductive biology of the threatened palm species Butia eriospatha. Journal of Heredity 2012; 103(6): 842-852. 10.1093/jhered/ess070

Negrelle RRB, Degen-Naumannn RL. Copernicia alba Morong ex Morong \& Britton: aspectos botânicos, ecológicos, etnobotânicos e agronômicos. Visão Acadêmica 2012; 13(2): 60-71.

Newstrom LE, Frankie GW, Baker HG. A new classification for plant phenology based on flowering patterns in lowland tropical rain forest trees at La Selva, Costa Rica. Biotropica 1994; 26(2): 141-159. 10.2307/2388804 
Piña-Rodrigues FCM, Aguiar IB. Maturação e dispersão de sementes. In: Aguiar IB, Piña-Rodrigues FCM, Figliolia MB, editors. Sementes florestais tropicais. Brasília, DF: Abrates; 1993. p. 215-274.

Pott A, Pott VJ. Plantas do pantanal. Corumbá: Embrapa; 1994.

Rebelatto D, Leal TS, Moraes CP. Fenologia de duas espécies de ipê em área urbana do município de Araras, São Paulo, Brasil. Revista da Sociedade Brasileira de Arborização Urbana 2013; 1(8): 1-16.

Rocha TGF, Silva RAR, Dantas EX, Vieira FA. Fenologia da Copernicia prunifera (Arecaceae) em uma área de caatinga do Rio Grande do Norte. Cerne 2015; 21(4): 673-682. 10.1590/01047760201521041758

Salgado CR. Flora melifera en la Provincia del Chaco. Buenos Aires: PROSAP; 2006.

Sano SM, Fonseca CEL, Ribeiro JF, Oga FM, Luiz AJB. Folhação, floração, frutificação e crescimento inicial de cagaiteira em Planaltina, DF. Pesquisa Agropecuária Brasileira 1995; 30(1): 5-14.
Souza DNN, Camacho RGV, Melo JIM, Rocha LNG, Silva NF. Estudo fenológico de espécies arbóreas nativas em uma unidade de conservação de caatinga no estado do Rio Grande do Norte, Brasil. Biotemas 2014; 27(2): 31-42. 10.5007/2175-7925.2014v27n2p31

Tannus JLS, Assis MA, Morellato LPC. Fenologia reprodutiva em campo sujo e campo úmido numa área de cerrado no sudeste do Brasil, Itirapina - SP. Biota Neotropica 2006; 6(3). 10.1590/S1676-06032006000300008

Valentini CMA, Almeida JD, Coelho MFB, Rodríguez-Ortíz CE. Fenologia da Siparuna guianensis Aublet em dois bosques de preservaçãoo ambiental em Cuiabá-MT. Cerne 2013; 19(4): 581-591. 10.1590/S0104-77602013000400008

Vilela GF, Carvalho D, Vieira FA. Fenologia de Caryocar brasiliense Camb. (Caryocaraceae) no Alto Rio Grande, sul de Minas Gerais. Cerne 2008; 14(4): 317-329. 